\title{
Factors of impact on the evolution of electricity markets from renewable energy sources: a comparison between Romania and Germany
}

\section{Roxana CLODNIȚCHI}

\author{
Bucharest University of Economic Studies, Bucharest, Romania
}

\section{Alexandra Cătălina CHINIE}

\author{
Bucharest University of Economic Studies, Bucharest, Romania
}

\begin{abstract}
When talking about the future of Europe we also think about alternative energy sources. It is up to national governments to decide how to encourage investments in this field in order to contribute to the 20-20-20 EU-objective. Until the network delivery cost for electricity produced from renewable sources will be comparable to the cost for energy from traditional sources ("grid parity"), the development of businesses and markets for electricity from renewable sources is going to be driven by support schemes. The state of the grids and the facility of grid-access constitute another two key factors influencing the development of this sector. Last but not least, the question of policy consistency is raised within the business community. Over the past years some support schemes have proved to be more effective than others, and grid conditions have also evolved. Policies supporting the development of renewables also changed at EU-level and at national levels. Based on statistics, scientific literature and the feedback of the business community, this study aims to analyse the development of renewable energy sectors in the European Union by comparing Germany's and Romania's experience. Also this study describes the current and expected future market situation in these countries relying on data gained from questionnaires and interviews with specialists in the renewable field.
\end{abstract}

Keywords: renewable energy, energy markets, support schemes, electricity, feed in tariffs, green certificates.

Please cite the article as follows: Clodnițchi, R. and Chinie, C. (2015), "Factors of impact on the evolution of electricity markets from renewable energy sources: a comparison between Romania and Germany", Management \& Marketing. Challenges for the Knowledge Society, Vol. 10, No. 1, pp. 33-51, DOI: 10.1515/mmcks-2015-0003.

\section{Introduction}

Scarcity of resources and climate change are more visible than ever today. The decreasing levels of fossil energy sources are a global concern, affecting developed and developing countries as well. Governments have realized that a stimulating legislative framework is crucial in order to promote alternative energy sources and a sustainable development.

In January 2007, the European Commission presented the Renewable Energy Roadmap, which set as objectives to reduce gas emissions by at least $20 \%$ until 2020, compared to 1990 levels (by 30\% if possible), to increase the share of renewable energy in final energy consumption to $20 \%$, and to achieve a $20 \%$ increase in energy efficiency. It is estimated that meeting the $20 \%$ renewable energy target could have a net effect of creating over 400.000 additional jobs (European Commission, 2014). In order to reach the ambitious target of a $20 \%$

Correspondence: Roxana Clodnițchi clodnitchi@yahoo. com 
share of energy from renewable sources in the overall energy mix, the European Union focused its efforts on the electricity, heating and cooling sectors and on biofuels. This paper addresses mainly the issue of electricity gained from renewable energy sources.

Prior studies have not identified significant correlations between the share of renewable energy in the gross energy consumption of a country and its level of greenhouse gas emissions, its GDP or its energy intensity (Nichifor et al., 2013). The low level of this correlation is attributed to the existence of other factors that influence the decision of using renewable energy at a large scale. Within this scientific approach we intend to analyse the main political factors influencing the development of renewable energy markets.

The Member States have taken on binding national targets for raising the share of renewable energy in their energy consumption depending on their different current conditions and potential for increasing renewables production. These goals range from $10 \%$ in Malta to $49 \%$ in Sweden. Germany, Europe's greatest energy producer and consumer, set its target to $18 \%$, while Romania, a traditional producer of energy from renewable sources in South East Europe, set its target at 24\% (European Commission, 2014). Since electricity does not generate CO2-emissions at end use, is available in almost all stages of its production, transmission, and consumption and is also an efficiently transformable energy carrier, many support schemes focus on the electricity production from renewable energy sources. This also constitutes the subject of our study.

Member States further on individually decided on how to transpose the Renewable Energy Directive into national laws, including the choice of the support system for electricity generated from renewable sources. This study aims to explore the different support schemes and to show that market development for electricity from renewable sources depends on the support scheme chosen by the Member State. A secondary goal is to determine which type of support scheme will better serve the goals in the long run: Does the EU encourage the best type of support schemes? Is the scheme preferred by investors also the most effective one?

Next to the chosen support system, arises the question of an appropriate infrastructure. Is the electricity grid - transport and distribution - adequate for the development of renewable sources? Can a renewable energy producer get connected easily to the grid and at what cost? Also it is important to note in what degree the framework conditions are constant. In this assessment the feedback of the business community is taken into account, by using structured and unstructured interviews, as well as findings of a prior study conducted by Bürer and Wüstenhagen in 2007 (Bürer and Wüstenhagen, 2009). In order to gain perspective of the development of the European market, the study explores statistical data provided by the European Statistical Office but also by EUobserver and by national profile associations correlated with the specific support schemes.

In order to get a better perspective of the Romanian market, we drew a comparison to Germany, Europe's forerunner in all green tech related questions. Romania and Germany both registered great progress in the renewable sector but have different kind of support schemes in place. While Romania chose a selfadjusting subvention system relying on quota obligations and green certificates, Germany grants renewable energy producers special feed-in-tariffs for 20 years after installation.

Vol. 10, No. 1, Spring, pp. 35-51, ISSN 1842-0206 | Management \& Marketing. Challenges for the Knowledge Society 
While Romania still relies on its traditional centralised electricity system, Germany relies on smart grids and a fragile balance between centralised and decentralised power generation. Romania still has to transpose the acquis on smart grids, firstly with smart metering and the next step is related to integration of renewables in Romanian grids. However, during the last years, over $3200 \mathrm{MW}$ in wind power, over $1200 \mathrm{MW}$ in solar PV and in general almost $5000 \mathrm{MW}$ have been installed in renewable power generation from private funds. All solar PV, all smallhydro, and a big part of wind power new plants representing decentralized generation systems are connected to the distribution grid and generate difficulties for all the parts involved in the system's equilibration. Both countries underwent changes regarding to legislation in this sector, and the next chapters will address these matters more thoroughly.

The European Commission considers that harmonisation of the rules in the renewable energy sector is not feasible at present but it is the path that should be taken in the long term. Subsequently it raises the question of the kind of policy framework that can contribute best to a sustainable development in the energy sector, question we would like to address in this research.

\section{Conceptual framework Support systems}

Each Member State chose how to implement the 20-20-20 targets into its national strategy and legislation. They established national action plans which set the share of energy from renewable sources consumed in the production of electricity as well as in heating and cooling and also transport for 2020 (European Commission, 2010). These plans establish procedures for the reform of planning and pricing schemes and access to electricity networks, promoting energy from renewable sources. So far the support systems can be categorised as follows (Official Journal of the European Union, 2004):

1. Feed-in-Tariffs (FITs) are the most common electricity from renewable energy sources (further on "RES-E") support instrument in the EU: These systems are characterised by a technology-specific price that must be paid for a period of up to 20 years (normally set around seven years) by electricity companies, usually distributors, to domestic producers of green electricity.

2. Premium Feed-in-Tariffs (FIPs): Under a premium tariff system, renewable electricity is sold in the wholesale market, and generators receive a fixed premium in addition to the electricity market price.

3. Contracts for Differences (CFDs): Under a CFD system, renewable energy generators receive the difference between a cost-based technology-specific "base level" and an index reflecting the average electricity market price.

4. Quota Obligations and Renewable Energy Certificates (QO+RECs): RES-E is sold at the conventional market price. In order to finance the additional cost of producing green electricity, and to ensure that it is generated in sufficient quantities, all consumers are obliged to purchase a certain number of green certificates from RES-E producers according to a fixed percentage (quota) of their total electricity consumption/generation.

5. Capacity Procurement Auctions (CPAs): the State issues a series of invitations to tender for the supply of RES-E, which will be sold at market price. The additional cost is passed on to the final consumer in the form of a special tax. 
Tender schemes are not used any longer as the dominating policy scheme in any Member State, but in some cases they are used for specific projects or technologies (e.g. wind offshore in Denmark) (DNV GL, 2014).

6. Tax incentives.

7. Hybrid Instruments: many European countries apply a mix of the aforementioned regulatory instruments.

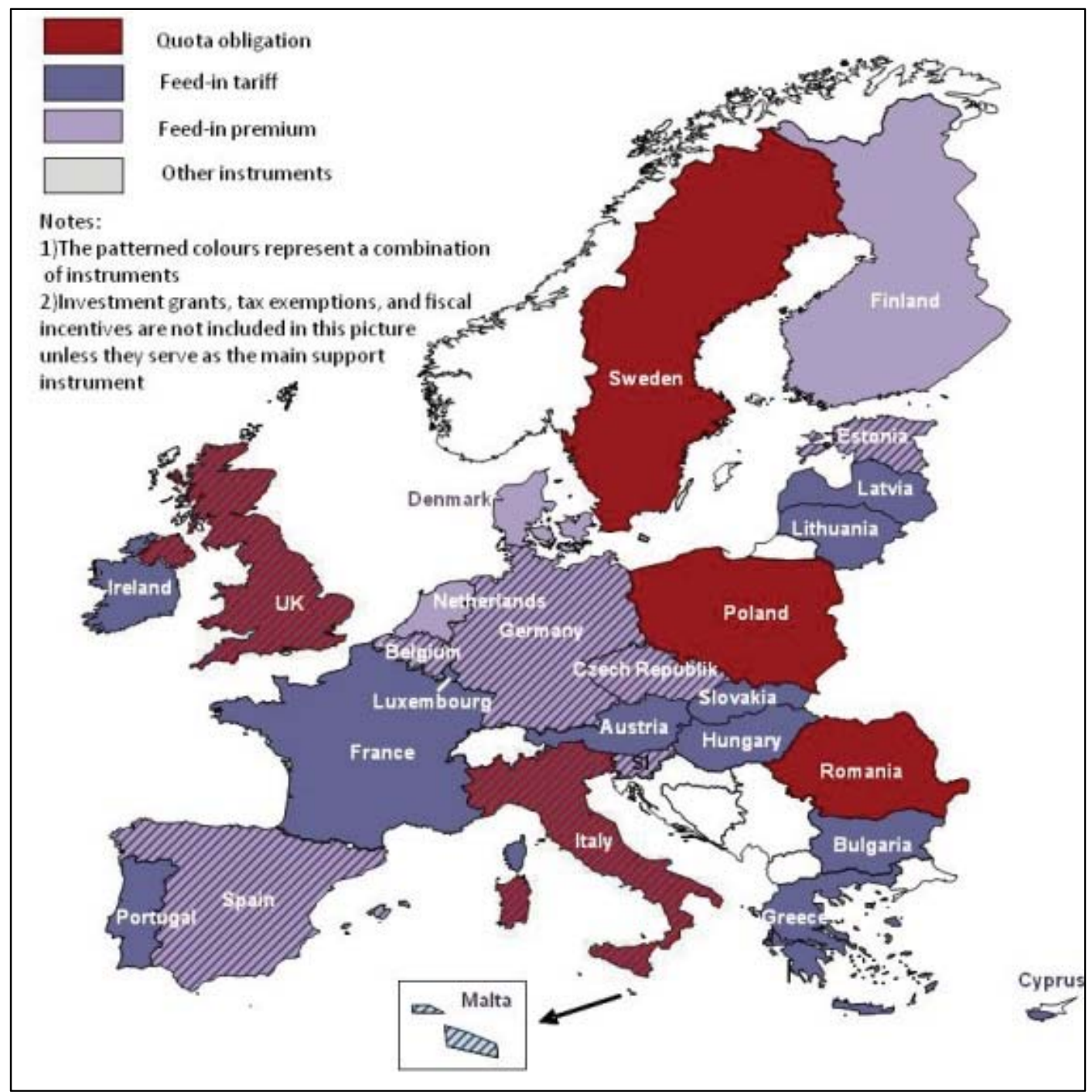

Figure 1: Overview of main RES-E support schemes in EU27

Source: www.reshaping-res-policy.eu/downloads/Final\%20report\%20REShaping_Druck_D23.pdf

As can be seen in Figure 1, feed-in tariffs and premiums, and quota obligation systems dominate the applied support schemes. Feed-in tariffs and premiums are applied as the main instrument in 20 Member States. Quota systems with tradable green certificates are applied in five states: Italy, Poland, Sweden, the United Kingdom and Romania (Ragwitz et al., 2012).

In order to take a closer look at the two predominant support schemes we chose to draw a comparison between Romania - a country considered for a short 
MMCKS while to be one of the most attractive renewable energy markets in Europe - and Germany - a country that according to EY ranks $3^{\text {rd }}$ worldwide in the same matter (Ernst \& Young Global Limited, 2014).

Romania implemented a combined system relying on compulsory quotas and green certificates, which promotes the production of electricity from renewable sources. The law obliges all electricity suppliers to annually meet prior set quotas of renewable energy in the energy mix. This means that a certain percentage of the amount of electricity supplied to the end consumer should come from renewable sources. The supplier reaches the set rate by purchasing a number of green certificates. The renewable energy producer receives for every Mega Watt hour (MWh) fed into the system, next to the market price for electricity (when it trades the energy), a certain amount of green certificates - for PV, the law stipulates 3 certificates/MWh, for wind energy 1 certificate, for biomass and biogas up to 3 certificates. Remuneration consists of the current price for electricity and an additional compensation received from the traded green certificates. The certificates may be traded on a specialised market in the price range $€ 27-55 /$ piece + Euro-inflation.

In the research performed by Bürer and Wüstenhagen (2009), aimed specifically at identifying the renewable energy policies that foster renewable energy best, policies are split in two categories: market-pull policies and technology-push policies. Most effective technology-push policies, according to their study, are government demonstration grants, public R\&D and grants for small and medium companies, while most effective market-pull policies (with an overall average rating higher than technology-push policies) are feed-in-tariffs, reduction of fossil fuel subsidies and technology performance standards. Although countries that use a feed-in-tariff policy have been more successful with the development of the RES-E sectors than others, the instrument may not be efficient on the long-run due to the preclusion of price competition among renewable developers, corroborated by the high transmission investment costs (Alagappan et al., 2011).

Still, certain authors stress that a system based on QO+RECs, not only permits to obtain the desired level of renewable energy market share easier, but also is characterised by a better cost-efficiency. Support schemes involving trading mechanisms are however often perceived as advantageous for big companies, having neutral or negative effects on smaller, entrepreneurial firms (Toke and Lauber, 2007; Schleich and Betz, 2005). They also have the disadvantage of distorting the competition (Danuletiu et al., 2013).

A FIT-System on the other hand can only work as long as investors' risk aversion is moderate (Fagiani et al., 2013) and can only be as efficient as a $\mathrm{QO}+\mathrm{REC}$ system as long as the regulator sets adequate tariffs levels. Being based on average cost estimations, these could result in either low effectiveness or overinvestment. Fagiani et al. (2013) also warn that regulators' estimations could be far from perfect, for example they could be manipulated by sector lobbies aiming to obtain higher benefits for their companies. Due to the rapid changes in technology prices a QO+RECs system can also lead to overcompensation in the initial phase of the investment, but make the investor's initial business plan economically unfeasible later on, due to the government's too long set respond time for adjustments. In Romania's case there was, according to some authors, an excessive support of the RES-E generated by political decisions that were not very rigorously 
substantiated from an economical point of view (Grecu, 2014). The possibility to correct/adjust the support level was given only after an elapsed period of time, time in which more investments were made than initially expected. Due to the closeness of PV and wind energy to reach grid parity in Europe (Roland Berger, 2011), to the fact that PV and wind energy generation cost already lay below conventional sources in some parts of the world [1] (Cardwell, 2014), the PV and wind energy businesses are considered to be less risky and engaged the majority of investors in Romania.

Bürer and Wüstenhagen (2009) find that feed-in-tariffs are rather perceived as effective by a wide variety of fund manager types with a variety of characteristics at stimulating investor interest to invest in new renewable energy technologies. Haas et al. (2010) also state that systems relying on feed-in tariffs are more effective and economically efficient. The lower level of risk involved makes this kind of system more attractive for investors, which leads to higher levels of new renewable energy investments (Mitchell et al., 2006). More and more authors argue that FIT-schemes are only successful in terms of increasing the numbers of RES-E facilities and the quantity of electricity produced by renewable resources. In Germany this system has accomplished this at a cost that is huge relative to the energy and environmental values provided by those resources (Morey and Kirsch, 2014). According to Morey and Kirsch (2014), these "well-intentioned" laws have proved to be an extraordinarily wasteful means of supporting improvements in environmental quality and reducing greenhouse gas emissions.

Policy formulation for renewable energy support must be addressed in a multi-criteria context (San Cristobal, 2011), and they have been limited in taking into account the investor's perspective for policies (Masini and Menichetti, 2012). In a research performed by Negro et al. (2012), the slow diffusion process of renewable energy is explained by two paradigms: support mechanisms aiming to compensate for private underinvestments have been weak in identifying where they should be targeted to and to what level; the second paradigm is based on creating, through policies, a favourable environment for the development of innovations.

\section{The evolution of the E-RES support systems in Romania and Germany}

In order to better evaluate the influence factors of market evolution, we consider it necessary to look at the evolution of the E-RES support mechanisms in the two countries. A long-term and stable policy environment has been pointed out by several authors (Held et al., 2006; Marin, 2013) as a key criterion for the success of developing renewable electricity markets. The International Energy Agency warns in its latest report that the expansion of renewable energy will slow over the next five years unless policy uncertainty is diminished (International Energy Agency, 2014).

The support framework has changed in the past years. In the context of financial austerity, 2012 came with incentives' cuts for solar support. Moreover, countries such as Spain, the Czech Republic, Greece and Bulgaria have announced retroactive cuts (Frankfurt School, 2014). In 2013 and 2014 legislative changes have led among other things to the reduction of the number of certificates issued for wind power or photovoltaics in Romania. This measure does not directly affect all renewable energy sectors but was blamed for generating instability. It 
MMCKS represents a new legal precedent, just a few months after implementing some other legislative changes affecting also projects already implemented.

The former legislation established annual quotas of green certificates until 2020. These quotas will now be set annually, thus reducing the predictability of the system. Also the mandatory quota for 2014 has been reduced substantially from the initial rate provided in the initial legal text. In a system where the price of certificates is determined by supply and demand, this measure affects both new investors and those already active in the market. For amending the support system in Romania since 2008, there were issued 14 Government Decisions, 3 Government Emergency Ordinances, 2 Government Ordinances and 4 laws.

Germany also experiences cuts in the support of E-RES. The basic law from 2000 suffered however only 4 amendments since then, namely in 2004, 2009, 2012 and 2014. According to the German Ministry of Economic Environment and Energy, the reductions of the feed-in-tariffs aim to encourage innovation in the system and also to assure food security. The introduction of feed-in-premiums and other compensatory mechanisms (like feed-in-on-demand premiums) aim to keep the market attractive for investors and to ensure system stability for the further pursue of Germany's energy goals depicted in Germany's Energy Transition Strategy (Energiewende - phasing out nuclear power, shift from fossil sources to renewable energy).

\section{Access to the grid}

It is also necessary to analyse whether the success of a particular policy results above all from substantial financial incentives or whether there are other aspects need to be taken into consideration. Some authors argue that there is a strong need for a renewable energy partnership between public authorities, business community and civil society in order to achieve the regional development of renewable energy (Zamfir, 2012). In prior scientific approaches we outlined the necessity to support collaboration models like green clusters for the development of renewable energy technologies and markets (Tanțău and Chinie 2012; Chinie, 2014).

Another parameter identified by several authors to be of great importance in order for a renewables market to develop is the access of renewable energy producers to the grid (Gerwen, 2006; Zane et al., 2012; Marin, 2013). Romania makes efforts in order to liberalize the energy market which is considered a priority by the International Monetary Fund and the European Union. Theoretically speaking, the Romanian energy market is fully liberalized for corporate and household customers because more than half of the supply is provided under free market arrangements (Pacesila, 2013).

The access and connection to the grid of renewable energy producers is stated to be a priority at the national level by the current Energy Strategy and by the National Action Plan for Renewable Energy (Ministerul Economiei, Comerțului și Turismului, 2010; Ministerul Economiei, Comerțului și Turismului, 2011). These also underline the need to develop smart grids, but until now however, not much has happened. Furthermore, the National Strategy is currently under revision and it is yet unclear what the new paper will state regarding renewable energy.

In Romania, grid connection costs for electricity produced from renewable sources have a significant share in the total investment cost (Gerwen, 2006). 
Recent legislative changes compel RES-E generators applying for grid connection to pay not only for the specific installation connecting them to the grid, but also for the overall grid reinforcement. The distribution grid is in a poor condition compared to the transmission grid (Bozsoki et al., 2011). Even before this decision, grid operators were applying bureaucratic procedures. The interviewed market experts also complained about the indirect market barriers due to difficulties in connection to the distribution grid, but also about the state of the transmission grid. It is expected that especially the high number of wind plants will generate problems in future (Pacesila, 2013). Transelectrica, the administrator of the national transmission grid, approved in the past years several plans for the grid's development but the lack of funds and other obstacles generate difficulties in performing the work. The question of "shallow" or "deep" grid connection fees still constitutes the subject of many debates among regulatory experts.

Germany faces similar problems. The restructuring of its electricity sector requires considerable technological efforts consisting of new renewable technologies, increased energy efficiency, storage capacities and smart grids. The development of the distribution grid was accelerated based on modern technologies as well as on the acceleration of authorization procedures (Marin, 2013).

The development of the transportation grid proves to be much more difficult, especially since great energy production facilities have developed and are expected to develop in Germany's north region (e.g. off-shore wind parks) while the intensive industrialised areas which require large amounts of energy are located in the middle and in the south of the country. Centralised generation solutions have to work complementary to decentralised generation solutions. The widely implemented distributed generation concept and these systems' correlation with the centralised suppliers require great energy management efforts (VDE, 2007).

\section{Research methodology}

We take a look at the market development in the RES-E field, dividing the European markets according to the chosen support system. Table 1 shows the development of the share of RES-E in each European Member State. The countries are grouped according to the support schemes chosen: FIT (feed-in-tariff), FIP+FIT (feed-in-premium and combined feed-in-systems) and QO+RECs (Quota obligations and Renewable Energy Certificates).

\section{Table 1: Share of RES-E}

\begin{tabular}{|c|c|c|c|c|c|}
\hline $\begin{array}{c}\text { Countries } \\
\text { per support } \\
\text { scheme }\end{array}$ & $\begin{array}{c}\text { Electric } \\
\text { energy } \\
\text { available for } \\
\text { final } \\
\text { consumption } \\
\mathbf{2 0 0 4}(\mathbf{G W h})\end{array}$ & $\begin{array}{c}\text { Share of RES-E } \\
\text { in final } \\
\text { electricity } \\
\text { consumption } \\
\mathbf{2 0 0 4}\end{array}$ & $\begin{array}{c}\text { Share of RES- } \\
\text { E in final } \\
\text { electricity } \\
\text { consumption } \\
\mathbf{2 0 0 8}\end{array}$ & $\begin{array}{c}\text { Share of } \\
\text { RES-E in } \\
\text { final } \\
\text { electricity } \\
\text { consumption } \\
\mathbf{2 0 1 2}\end{array}$ & $\begin{array}{c}\text { Compound } \\
\text { annual } \\
\text { growth } \\
\text { rate for the } \\
\text { share of } \\
\text { RES-E (\%) }\end{array}$ \\
\hline FIT & & & & & \\
\hline Austria & $56,777.00$ & $62.00 \%$ & $64.80 \%$ & $65.50 \%$ & $0.70 \%$ \\
\hline Bulgaria & $24,951.00$ & $9.50 \%$ & $10.70 \%$ & $17.00 \%$ & $7.50 \%$ \\
\hline Croatia & $13,702.00$ & $32.50 \%$ & $30.80 \%$ & $35.50 \%$ & $1.10 \%$ \\
\hline Cyprus & $3,750.00$ & $0.10 \%$ & $0.30 \%$ & $4.90 \%$ & $62.70 \%$ \\
\hline
\end{tabular}

Vol. 10, No. 1, Spring, pp. 35-51, ISSN 1842-0206 | Management \& Marketing. Challenges for the Knowledge Society 


\begin{tabular}{|c|c|c|c|c|c|}
\hline Denmark & $32,970.00$ & $23.80 \%$ & $25.90 \%$ & $38.70 \%$ & $6.30 \%$ \\
\hline France & $420,165.00$ & $13.80 \%$ & $14.40 \%$ & $16.60 \%$ & $2.30 \%$ \\
\hline Greece & $49,738.00$ & $7.90 \%$ & $9.70 \%$ & $16.50 \%$ & $9.60 \%$ \\
\hline Hungary & $31,818.00$ & $2.20 \%$ & $5.30 \%$ & $6.10 \%$ & $13.60 \%$ \\
\hline Ireland & $23,209.00$ & $6.00 \%$ & $11.10 \%$ & $19.60 \%$ & $15.90 \%$ \\
\hline Latvia & $5,404.00$ & $46.00 \%$ & $38.70 \%$ & $44.90 \%$ & $-0.30 \%$ \\
\hline Lithuania & $7,650.00$ & $3.60 \%$ & $4.90 \%$ & $10.90 \%$ & $14.90 \%$ \\
\hline Luxembourg & $6,382.00$ & $2.80 \%$ & $3.60 \%$ & $4.60 \%$ & $6.40 \%$ \\
\hline Portugal & $44,668.00$ & $27.50 \%$ & $34.10 \%$ & $47.60 \%$ & $7.10 \%$ \\
\hline Slovakia & $24,027.00$ & $10.30 \%$ & $16.00 \%$ & $20.10 \%$ & $8.70 \%$ \\
\hline $\begin{array}{c}\text { Average } \\
\text { indicators for } \\
\text { FIT }\end{array}$ & $53,229.36$ & $17.71 \%$ & $19.31 \%$ & $24.89 \%$ & $11.18 \%$ \\
\hline \multicolumn{6}{|l|}{ FIP+FIT } \\
\hline Belgium & $80,614.00$ & $1.70 \%$ & $4.60 \%$ & $11.10 \%$ & $26.40 \%$ \\
\hline $\begin{array}{c}\text { Czech } \\
\text { Republic }\end{array}$ & $53,832.00$ & $3.60 \%$ & $5.20 \%$ & $11.60 \%$ & $15.70 \%$ \\
\hline Estonia & $5,913.00$ & $0.60 \%$ & $2.10 \%$ & $15.80 \%$ & $50.50 \%$ \\
\hline Finland & $83,054.00$ & $26.70 \%$ & $27.30 \%$ & $29.50 \%$ & $1.30 \%$ \\
\hline Germany & $521,268.00$ & $9.40 \%$ & $15.10 \%$ & $23.60 \%$ & $12.20 \%$ \\
\hline Malta & $1,790.00$ & $0.10 \%$ & $0.10 \%$ & $1.10 \%$ & $35.00 \%$ \\
\hline Netherlands & $104,715.00$ & $4.40 \%$ & $7.50 \%$ & $10.50 \%$ & $11.50 \%$ \\
\hline Slovenia & $12,546.00$ & $29.30 \%$ & $30.00 \%$ & $31.40 \%$ & $0.90 \%$ \\
\hline Spain & $230,669.00$ & $19.00 \%$ & $23.70 \%$ & $33.50 \%$ & $7.30 \%$ \\
\hline $\begin{array}{c}\text { Average } \\
\text { indicators for } \\
\text { FIP+FIT }\end{array}$ & $121,600.11$ & $10.53 \%$ & $12.84 \%$ & $18.68 \%$ & $17.87 \%$ \\
\hline \multicolumn{6}{|l|}{ QO+RECs } \\
\hline Italy & $295,555.00$ & $16.20 \%$ & $16.80 \%$ & $27.60 \%$ & $6.90 \%$ \\
\hline Poland & $104,667.00$ & $2.10 \%$ & $4.30 \%$ & $10.70 \%$ & $22.60 \%$ \\
\hline Romania & $38,775.00$ & $28.40 \%$ & $28.10 \%$ & $33.60 \%$ & $2.10 \%$ \\
\hline Sweden & $130,361.00$ & $51.20 \%$ & $53.60 \%$ & $60.00 \%$ & $2.00 \%$ \\
\hline $\begin{array}{c}\text { United } \\
\text { Kingdom }\end{array}$ & $338,947.00$ & $3.50 \%$ & $5.50 \%$ & $10.80 \%$ & $15.10 \%$ \\
\hline $\begin{array}{c}\text { Average } \\
\text { indicators for } \\
Q O+R E C S\end{array}$ & $295,555.00$ & $16.20 \%$ & $16.80 \%$ & $27.60 \%$ & $6.90 \%$ \\
\hline
\end{tabular}

Source: www.eurostat.eu

In order to analyze if the presented indicators influence the renewable energy growth rate we computed the correlations between the following indicators using the Pearson correlation coefficient in SPSS: the amount of electric energy available for final consumption 2004 (GWh), the share of renewable energy in the final consumption $2004(\%)$, and the compound annual growth rate (CAGR) of the renewable energy share $(\mathrm{V})$ determined by using the calculation formula:

where t0 is 2004 , tn is 2012 .

$$
\operatorname{CAGR}\left(t_{0}, t_{n}\right)=\left(V\left(t_{n}\right) / V\left(t_{0}\right)\right)^{\frac{1}{t_{n}-t_{0}}}-1(1)
$$

In order to assess the current situation in the Romanian and German markets, our research group conducted in the period of October 2013 - March

Vol. 10, No. 1, Spring, pp. 35-51, ISSN 1842-0206 | Management \& Marketing. Challenges for the Knowledge Society 
2014 interviews with 26 experts, 10 of which are active exclusively in Romania, 15 are active in both countries and one of them is active in Germany, but planning to become active in Romania as well. The questionnaire consisted of two parts: the first part referred to characteristics of the business model already implemented by the respondent, and the second part was related to future expectations regarding the development of the renewable energy market and models.

\section{Results and analysis}

Based on the Eurostat data regarding the market development for electricity from renewable sources in the European countries, there was no statistically significant correlation found between the chosen support mechanism and the compound growth rate of the share of RES-E. However, a significant correlation was found between the share of electricity from renewable energy sources and its compound annual growth rate. According to the Pearson coefficient, a higher share of RES-E in final electricity consumption in 2004 may have led to a smaller compound annual growth rate (see Table 2).

Table 2: Correlations between Indicators

\begin{tabular}{|c|c|c|c|}
\hline & $\begin{array}{c}\text { Electric energy available } \\
\text { for final consumption } \\
2004 \text { (GWh) }\end{array}$ & $\begin{array}{c}\text { Share of RES-E in } \\
\text { final electricy } \\
\text { consumption } 2004\end{array}$ & $\begin{array}{l}\text { Compound annual } \\
\text { growth rate for the } \\
\text { share of RES-E (\%) }\end{array}$ \\
\hline Energy & 1.000000 & & \\
\hline $\begin{array}{l}\text { RES-E- } \\
\text { share }\end{array}$ & -0.05 & 1.000000 & \\
\hline CAGR & -0.183 & $-0.599 * *$ & 1.000000 \\
\hline
\end{tabular}

The highest average compound annual growth rate for renewable energy was achieved by countries using feed-in-premium and a combined feed-in system, which are also characterized by having the smallest average renewable energy share in 2004: with an average share of renewable energy of $11 \%$ in 2004, they achieved a compound annual growth rate of $18 \%$ in 2012 . The preferred support system for the top seven countries in terms of renewable energy share has been the feed-in-tariff system, according to the Eurostat data: four out of the seven countries with a renewable energy share equal or higher than $27.5 \%$ in 2004 have chosen the feed-in-tariff system, while two chose the green certificates system and one chose the combined feed-in-system. However, the highest growth rate among these countries was attributed to those using the green certificates system.

If split into four groups of seven according to their RES-E share, three out of the seven countries with the lowest RES-E shares in 2004 (equalling the top 25\%), have chosen the simple feed-in-tariff system, three have chosen the combined feedin-system, while one chose the green certificates mechanism. Although they reached an average compound growth of 31\% between 2004 and 2012, compared to the average compound growth of $2 \%$ registered by the top seven countries, their share of renewable energy in 2012 was still significantly low, at an average of $8 \%$.

The most significant growth of the amount of RES-E available for final consumption between 2004 and 2012 is attributed to countries using combined 
MMCKS feed-in-tariff and premium systems, at $17.87 \%$. However, these countries are also characterized by the lowest share of RES-E in 2004.

Romania belongs to the group of countries that have a high share of renewable energy - its energy mix traditionally strongly relies on hydropower (Kleps and Dascalescu,2010), as depicted in Figure 2. Mainly due to the large hydro power plants installed, Romania in 2004was already very close to achieving 33\% of the electricity production from renewable sources (objective fixed at EU level), factor that kept the pressure to build more capacities low. The allocation of resources and the investment inflow in Romania was later on triggered by the adoption of the Renewables Directive and of Law 220/2008 and the notification to and approval by the European Commission of the support scheme RES-E. Wind energy gained increasing importance over the last 4 years, leading to over 3200 MW installed but this sector will probably no longer develop, as feared by the interviewed experts. So far the lack of investments in the transmission grid did not directly affect the development of the Romanian renewable energy market. In near future however, further development of the sector will not be technically feasible. The lack of storage capacities, investments in the transmission grid and in smart grid development represent according to the interviewed experts barriers difficult to overcome.

Some experts as well as some authors underline the significance of biomass for Romania as the main renewable energy source (Ciubota-Rosie et al., 2008). Experts are referring however mainly to biomass as a feasible source for thermal energy appropriate for industrial and district heating, with power generation as a plus - in cogeneration units.

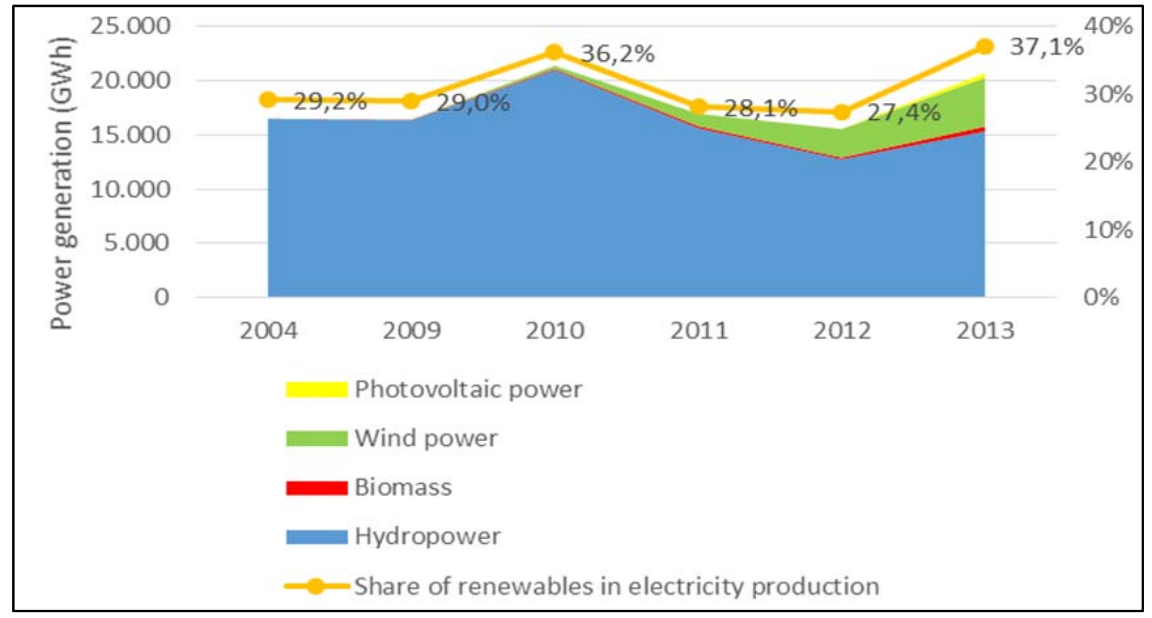

Figure 2: Share of RES-E in Romanian power generation

Source: Authors' own research results based on data from www.anre.ro, www.insse.ro.

Analysing the viewpoint of the business community, the legislative changes that took place in Romania between $2012-2014$ led to a predominantly negative perception of the external environment, $42 \%$ of the experts surveyed considering the current business environment (March 2014) of Romania as uncertain and lacking in opportunities as depicted in Figure 3. 


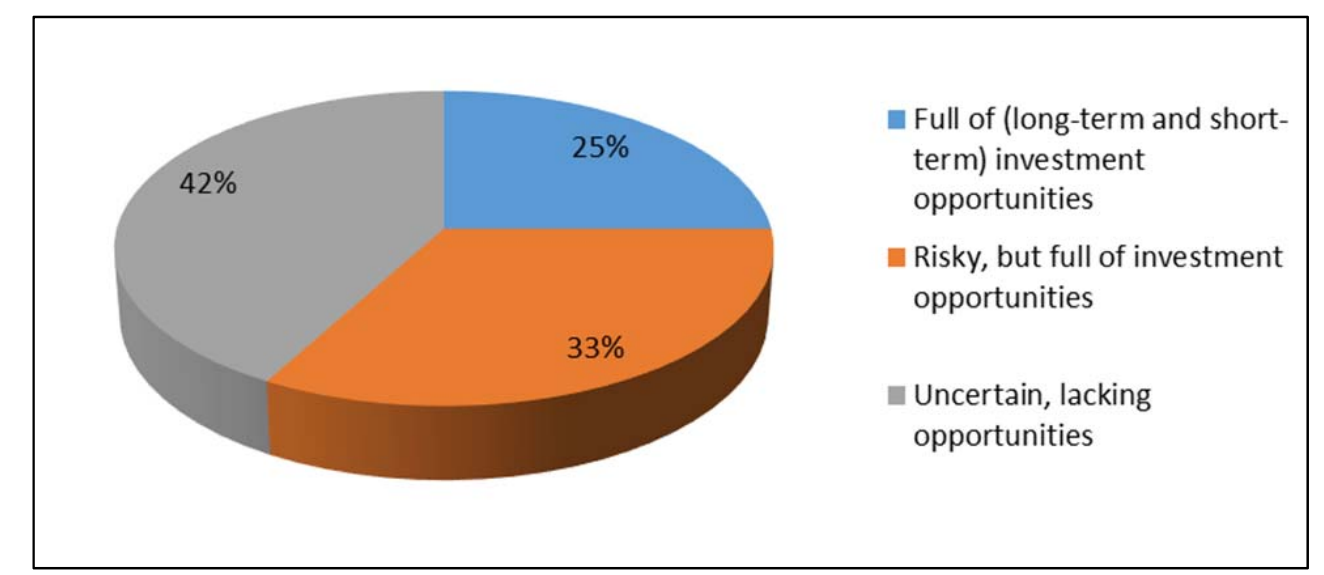

Figure 3: Perceived current context in the renewable energy sector in Romania Source: Authors' own research results.

Market perception depends also on the source of renewable energy the expert is interested in. While wind and solar energy experts are rather pessimistic about market development in Romania, only 14\% of the experts engaged in the biomass and biogas sector consider the Romanian investment environment as unsafe and lacking opportunities, due to the fact that the latest changes did not affect the number of green certificates granted to energy producers from biomass and biogas. The oversupply of green certificates in the market will probably lead shortly to worries among the experts in this sector.

The renewable energy sector in Germany is governed by a single law - The Renewable Energy Act (EEG, Erneuerbare-Energie-Gestez). Although it has changed over time, it still assures priority feed-in of RES-E into the distribution system, and guarantees a fixed feed-in-tariff for a period of 20 years. The majority of the surveyed experts have described the investment environment in Germany as full of opportunities for long-term investments, noting the feed-in tariff and premium system to be much more attractive than the green certificates system. Within our research group market experts expressed their preference for investments in Germany and their confidence in the German support system as depicted in Figure 4.

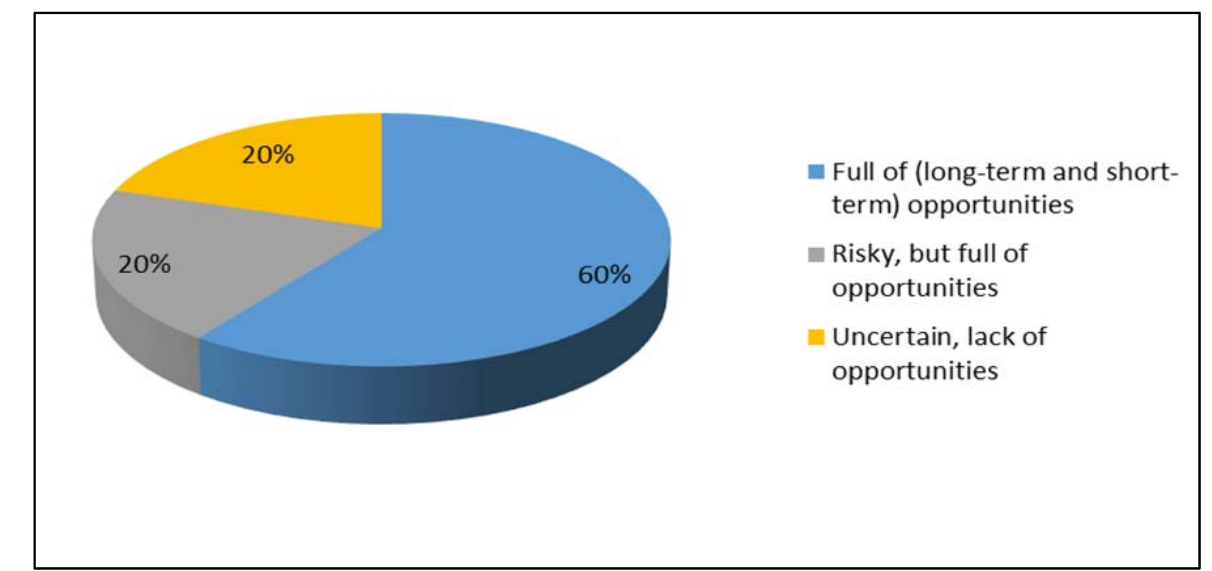

Figure 4: Perceived current context in the renewable energy sector in Germany

Source: Authors' own research results. 
According to these experts, implementing differentiated equitable feed-intariffs for different technologies should conduct to a more diversified development of renewable energy projects. The development of the German renewable energy market is a good example for this appreciation as depicted in Figure 5. Also, the reduction of feed-in-tariffs in Germany is not perceived as negative as the changes in the Romanian system.

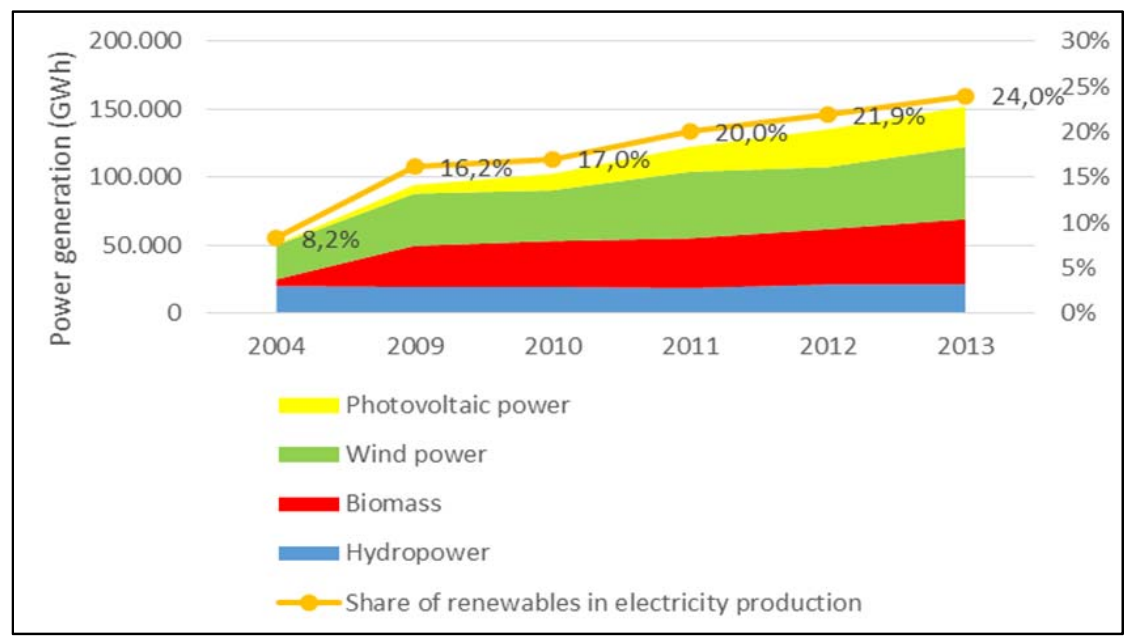

Figure 5: Share of renewable energy in the German power generation mix Source: Authors' own research results based on data from Agentur für Erneuerbare Energien, AG Energiebilanzen, www.bmu.de

The experts stressed the high importance of the regulatory drivers and the chosen support scheme in this sector, opinion also shared by several academic authors (Bürer and Wüstenhagen, 2009; Haas et al. 2010; Fagiani et al., 2013; Paecesila, 2013; Marin, 2013).

The 26 experts we interviewed confirmed the importance of the political factor, which significantly influences the decisions taken in renewable energy companies and also expressed their preference for a support scheme relying on feed-in-tariffs. This preference has also been identified by Bürer and Wüstenhagen (2009), who describe a positive correlation between the level of clean energy investment and a investments fund's preference for feed-in-tariffs. The average clean energy fund size for funds which rated feed-in-tariffs as highly effective was 107 million US\$ compared to only 12 million US\$ for funds which rated feed-intariffs as less effective (Bürer and Wüstenhagen, 2009).

In order to thoroughly asses the performance of the different support schemes it is also necessary to analyse the national, regional and agricultural resources of each Member State, which lead to differences in the generation costs for the same technology. In a UK versus Germany comparison conducted in 2004 by Butler and Neuhoff, they underline the lack of effectiveness of UK's quota obligation system. Since the prices paid for the amount of wind power that has been fed into the grid are similar to those in Germany, the scheme is less efficient despite poorer wind resources in Germany, (Butler and Neuhoff, 2004).

The participants to an older study regarding the development of the Romanian energy market (Clodniţchi, 2014) were asked to choose policy measures 
which they think would make the energy supply secure, affordable and MMCKS environmentally friendly on the short term (see Table 3).

Table 3: Desired policy measures to make the energy supply secure, affordable and environmentally friendly

\begin{tabular}{|c|c|}
\hline Measure & $\begin{array}{c}\text { Quotatio } \\
\text { ns }\end{array}$ \\
\hline Consistency of the policy measures & 69 \\
\hline Reduce taxes on electricity prices & 60 \\
\hline Better coordination of policies & 60 \\
\hline Strengthen competition in the electricity and gas market & 58 \\
\hline Promote upgrade of existing power plants with energy-efficient equipment & 55 \\
\hline Promote development of renewable energies & 54 \\
\hline Support network expansion & 53 \\
\hline Expand counselling and support for efficiency measures & 44 \\
\hline Approval of PPAs (power purchasing agreements) & 41 \\
\hline Promote construction of new and more efficient conventional power plants & 36 \\
\hline Improve conditions for new technologies ( e.g. expand energy research , \\
capture CO2) & 36 \\
\hline Tighten standards for energy efficiency & 31 \\
\hline Accelerate planning and approval process & 30 \\
\hline Privatization of existing power plants & 21 \\
\hline Increase acceptance for the changes in the energy sector & 20 \\
\hline Expansion of nuclear power by building a new nuclear power plant & 19 \\
\hline Development of new fossil energy sources (e.g. shale gas) & 13 \\
\hline Check subsidy budgets and special rules & 12 \\
\hline
\end{tabular}

It is interesting to observe, that, although the general perception of the development of Romania's energy sector is negative - valid for the respondents to this study as well as for the 26 experts interviewed - apart from the desired reduction of taxes, companies generally request conservative measures, limiting government intervention in the energy sector. Only 12 companies would appreciate a revision of subsidy scheme and special rules in the sector while, more than half of the participants to the study consider that renewable energy should be promoted further on. Most of all, the participants quoted the need for consistency of policy measures.

\section{Conclusions}

The main political factors influencing the development of electricity generation from renewable sources identified are the support mechanisms in place, grid development and access and policy consistency. Although the statistical data analysed does not provide clear findings regarding the choice of a certain support system's influence on the sector's development, the scholars' and business community's opinions state clearly that the development of businesses and markets for electricity from renewable sources is driven by support schemes. 
MMCKS In Germany as well as in Romania, the support systems have sustained and encouraged the rapid expansion of renewable energy production. However, support mechanisms relying on feed-in-tariffs and premiums - in place in Germany - are not only perceived as more attractive than those relying on renewable energy certificates - in place in Romania - but also are likely to determine slightly higher growth rates for the RES-E share in the final electrical energy consumption.

A limitation of the study is given due to the lack of recent statistical data. Romania's RES-E sector underwent in the past two years major developments, while Germany's sector developed at a constant pace, facts not depicted in the findings. Another limitation of this study is given by the disparity in the national, regional and agricultural resources of each Member State, which leads to differences in the generation costs for the same technology, as well as the influence which the status of RES-E share has on the future growth of the industry. The effectiveness of support schemes greatly depends on the energy source chosen to support. A system relying on quota obligations and renewable energy certificates will promote the installation of renewable energy capacities using technologies close to reach grid parity like the case of wind and PV in Romania, while feed-intariff or premium systems can promote the development of all technologies.

The scholars' opinion is divergent when it comes to the effectiveness and economic efficiency of the support schemes in place in the EU. While some argue that QO+RECs better permits to obtain the desired level of renewable energy market share and that they are characterised by a better cost-efficiency, others argue the exact opposite. QO+RECs have the disadvantage of distorting the competition and are often perceived as advantageous for big companies, having neutral or negative effects on smaller, entrepreneurial firms. The lower level of risk involved makes FIT-systems more attractive for investors, which leads to higher levels of new renewable energy investments. Although preferred by the business community, FIT-systems can only be efficient as long as the regulator sets adequate tariffs levels. FIT also may not be efficient on the long-run due to the preclusion of price competition among renewable developers, corroborated by the high transmission investment costs, factors that determined the EU to encourage the implementation of QU+RECs systems.

Other factors of great impact to the development of RES-E sectors are the state of the grids and the facility of grid-access, as stated by scholastic literature and the interviewed experts. Still, the rough comparison drawn between Romania and Germany shows that this did not have a major influence on the sector's development so far. The Romanian sector's present deadlock, however, shows that the issue is becoming apparent. The future should rely on a successful combination of centralised and decentralised generation with smart metering and smart grids. Investors interested in Romania express great hope today in the expected FIT system for small capacities that can only work correlated with grid developments.

Besides the system of choice and the transmission infrastructure development, another factor to be taken into account is the risk induced by political uncertainty or inconsistency of the promotion measures. This factor might have been more determinant for the business community to prefer the German promotion system, rather than the promotion scheme chosen by Romania. The retroactive support cutting measures implemented in Romania are likely to jeopardise Romania's successful development of the sector so close before calling 
in the targets to be reached. A consistent strategy with foreseeable goals and a clear plan regarding grid development - including the parts to be played by each stakeholder - as well as legislation issued accordingly may lead to a more positive investors' perception and to successful further development of the sector.

Future research should rely on technology-push instruments for the development of the renewable energy industry. Another paradigm worth bringing into future discussion is based on creating, through policies, of a favourable environment for the development of innovations.

Last but not least, an issue to be taken into account for the whole development approach is that the support mechanisms mainly regard electricity production independently from heat generation. Romania, for instance, where heat generation from biomass historically played and still plays the main part in the renewable energy consumption mix should pay more attention to this source and bring the temporarily abandoned biomass Master Plan from 2009 again into discussion when elaborating its new energy strategy for 2015-2035.

[1] Without subsidies, the investment banking firm Lazard's analysis shows that without subsidies wind energy costs about 3.7 cents (US Dollar) a kilowatt-hour and PV 7.2 cents a kilowatt-hour at the low end. In comparison, natural gas comes at 6.1 cents a kilowatt-hour on the low end and coal at 6.6 cents.

\section{Acknowledgements}

This work was co-financed from the European Social Fund through Sectoral Operational Programme Human Resources Development 2007-2013, project number POSDRU/159/1.5/S/142115 „Performance and excellence in doctoral and postdoctoral research in Romanian economics science domain"

\section{References}

Alagappan L., Orans S. and Woo, C.K. (2011), "What drives renewable energy development?", Energy Policy, Vol. 39, No. 9, pp. 5099-5104.

Bozsoki I., Zane E.B., Piria R., Frank R. and Bauknecht, D. (2011), Integration of electricity from renewables to the electricity grid and to the electricity market RES-INTEGRATION, National Raport: Romania, available online at: www.eclareon.eu/sites/default/files/romania_-_res_integration_national _study.pdf (accessed December 12, 2014).

Bürer, M.J. and Wüstenhagen, R. (2009), "Which renewable energy policy is a venture capitalist's best friend? Empirical evidence from a survey of international cleantech investors", Energy Policy, Vol. 37, No. 12, pp. 49975006.

Butler, L. and Neuhoff, K. (2004), "Comparison of Feed in Tariff, Quota and Auction Mechanisms to Support Wind Power Development", CMI/DAE Working paper 70.

Cardwell, D. (2014), "Solar and Wind Energy Start to Win on Price vs. Conventional Fuels", New York Times Energy \& Environment, available online at: www.nytimes.com/2014/11/24/business/energy-environment/solar-andwind-energy-start-to-win-on-price-vs-conventional-fuels.html?_r=0 (accessed December 10, 2014) 
MMCKS Chinie, A.C. (2014), "Current concerns and trends in the business of renewable energy", Management Research and Practice, Vol. 6, No. 4, pp. 5-22.

Ciubota-Rosie, C., Gavrilescu, M. and Macoveanu, M. (2008), "Biomass - an important renewable source of energy in Romania", Environmental Engineering and Management Journal, Vol. 7, No. 5, pp. 559-568.

Clodniţchi, R. (2014), "The latest developments in the Romanian energy sector: impact assessment and companies' reaction", Business Excellence Research 2014 Conference Proceedings, in press.

Danuletiu, D., Tamas-Szora, A., Socol, A. and Danuletiu, A. (2013), "Influence of the tradable green certificates on the financing policy of renewable energy companies in Romania" Journal of Environmental Protection and Ecology, Vol. 14, No. 3, pp. 1164-1170.

DNV GL - Energy in coop. with Imperial College and NERA Economic Consulting for the European Commission, DG Energy (2014), Integration of Renewable Energy in Europe. Final Report, available online at: ec.europa.eu/energy/renewables/doc/201406_report_renewables_integrati on_europe.pdf (accessed September 7, 2014).

Ernst \& Young Global Limited (2014), Renewable energy country attractiveness index available online at: www.ey.com/Publication/vwLUAssets/Renewable_ Energy_Country_Attractiveness_Index_41_-_June_2014/\$FILE/EYRenewable-Energy-Country-Attractiveness-Index-41-June-2014.pdf (accessed September 2, 2014).

European Commission (2010), Promotion of the use of energy from renewable sources, available online at: europa.eu/legislation_summaries/energy/ renewable_energy/en0009_en.htm (accessed September 14, 2014).

European Commission (2014), The 2020 climate and energy package, available online at: ec.europa.eu/clima/policies/package/index_en.htm (accessed August 7, 2014).

Fagiani, R., Barquín, J. and Hakvoort, R. (2013), "Risk-based assessment of the costefficiency and the effectivity of renewable energy support schemes: Certificate markets versus feed-in tariffs", Energy Policy, Vol. 55, April 2013, pp. 648-661.

Frankfurt School - UNEP Centre (2014), "Global Trends in Renewable Energy Investment", available online at: www.unep.org/pdf/Green_energy_2013Key_findings.pdf.

Gerwen R. (2006), "Producerea Distribuită și Regenerabile", available online at: www.sier.ro/Articolul_8_1.pdf (accessed December 3, 2014).

Grecu, E. (2014), "New technologies - Between business and environmental protection in Romania", Environmental Engineering and Management Journal, Vol. 13, No. 8, pp. 1873-1879.

Haas, R., Resch,G., Panzer, C., Busch, S., Ragwitz, M. and Held, A. (2010), "Efficiency and effectiveness of promotion systems for electricity generation from renewable energy sources: lessons from EU countries", Energy, Vol. 36, No. 4, pp. 1-8.

Held, A., Haas, R. and Ragwitz, M. (2006), On the success of policy strategies for the promotion of electricity from renewable energy sources in the EU, available online at: eeg.tuwien.ac.at/eeg.tuwien.ac.at_pages/publications/pdf/HAA_ PAP_2006_1.pdf (accessed November 12, 2014). 
International Energy Agency (2014), Renewable Energy Medium-Term Market Report 2014. Market Analysis and Forecasts to 2020. Executive Summary, available online at: www.iea.org/newsroomandevents/pressreleases/2014/ august/name-125080-en.html (accessed August 23, 2014).

Kleps, C. and Dascalescu, N. (2010), "Renewable energy resources in Romania between opportunities and constraints", Journal of Environmental Protection and Ecology, Vol. 11, No. 3, pp. 1131-1137.

Masini, A. and Menichetti, E. (2012), "The impact of behavioural factors in the renewable energy investment decision making process: Conceptual framework and empirical findings", Energy Policy, Strategic Choices for Renewable Energy Investment, Vol. 40, pp. 28-38.

Marin, G. (2013), "A comparative study on the European renewable energy sources facing globalization", Management \& Marketing. Challenges for the Knowledge Economy, Vol. 8, No. 4, pp. 723-746.

Ministerul Economiei, Comerțului și Turismului (2010), Planului Naţional de Alocare pentru Energii Regenerabile, available at: www.minind.ro/pnaer/ pnaer_29\%20iunie_2010_final_alx.pdf (accessed December 7, 2014).

Ministerul Economiei, Comerțului și Turismului (2011), Strategia energetică a României pentru perioada 2007-2020 actualizată pentru perioada 2011-2020, available online at: www.minind.ro/energie/STRATEGIA_energetica_ actualizata.pdf (accessed December 7, 2014).

Mitchell, C., Bauknecht, D. and Connor, P. (2006), "Effectiveness through risk reduction: a comparison of the renewable obligation in England and Wales and the feed-in system in Germany", Energy Policy, Vol. 34, pp. 297-305.

Morey, M. and Kirsch, L. (2014), "Germany's Renewable Energy Experiment: A Made-to-Order Catastrophe", The Electricity Journal Vol. 27, No. 5, pp. 6-20.

Negro, S.O., Alkemade F. and Hekkert, M.P. (2012), "Why does renewable energy diffuse so slowly? A review of innovation system problems", Renewable and Sustainable Energy Reviews, Vol. 16, No. 6, pp. 3836-3846.

Nichifor, M.A., Clodnițchi, R., Borisov, D. and Tanțău, A.D. (2013). "Correlations among the development of EU economies, energy intensity and renewable energy indicators", Management \& Marketing. Challenges for the Knowledge Society, Vol. 8, Special Issue, pp. 255-267.

Official Journal of the European Union, (2004), Support for electricity from renewable energy sources, available online at: eur-lex.europa.eu/legalcontent/EN/TXT/?qid=1410539736452\&uri=URISERV:124452 (accessed May 4, 2014).

Pacesila, M. (2013), “Analysis of the Balkan countries policy on renewable energy sources: the case of Bulgaria, Romania and Greece", Management Research and Practice, Vol. 5, No. 1, pp. 49-66.

Ragwitz, M., Steinhilber, S., Breitschopf, B., Resch, G., Panzer, C. et al. (2012), "REShaping: Shaping an effective and efficient European renewable energy market. Final Report", available online at: www.reshaping-res-policy.eu/downloads/ Final\%20report\%20RE-Shaping_Druck_D23.pdf (accessed August 12, 2014).

San Cristobal, J.R. (2011), "Multi-criteria decision-making in the selection of a renewable energy project in Spain: the Vikor method", Renewable Energy, Vol. 36, No. 2, pp. 498-502. 
MMCKS Schleich, J.and Betz, R. (2005), "Incentives for energy efficiency and innovation in the European Emission Trading System", Proceedings of the ECEEE 2005 Summer Study - what works and who delivers?.

51

Tanțău, A.D. and Chinie A.C. (2012) "Green clusters as a new business model for central and eastern Europe", 12th International Multidisciplinary Scientific GeoConference and EXPO - Modern Management of Mine Producing, pp. 499507.

Toke, D. and Lauber, V. (2007), "Anglo-Saxon and German approaches to neoliberalism and environmental policy: the case of financing renewable energy", Geoforum, Vol. 38, No. 4, pp. 677-687.

VDE Verband der Elektrotechnik, Elektronik Informationstechnik e.V. (2007), Dezentrale Energieversorgung 2020, available online at: www.vde.com/de/ fg/ETG/Pbl/Studien/Documents/MCMS/VDEStudieDezentraleEnergieversor gung2021.pdf (accessed December 10, 2014).

Zamfir, A. (2012), "Implementing Regional Renewable Energy Projects through Public-Private Partnerships", Business Excellence and Management, Vol. 2, No. 3, pp. 77-84.

Zane, E.B., Brückmann R., Bauknecht D., Jirous F., Piria R., Trennepohl N., Bracker J., Frank R. and Herling J. (2012), Integration of electricity from renewables to the electricity grid and to the electricity market - RES-INTEGRATION, available online at: www.oeko.de/oekodoc/1378/2012-012-en.pdf (accessed January $5,2015)$. 